\title{
Visualizing Service by Service Design Tools and PCN
}

\author{
Kyung Mi Bae ${ }^{1}$ and Youn Sung Kim ${ }^{2}$ \\ ${ }^{1}$ Dept. of International Trade and Regional Studies, Inha University \\ 100 Inha-Ro, Nam-Gu, Incheon 22212, KOREA \\ gracebae@inha.ac.kr \\ ${ }^{2}$ Dept. of Business Administration, Inha University \\ 100 Inha-Ro, Nam-Gu, Incheon 22212, KOREA \\ Corresponding Author: keziah@inha.ac.kr
}

\begin{abstract}
This study focuses on visualizing service by service design tools and PCN diagram in process innovation. Firstly, theoretical backgrounds of the phenomena will be reviewed for a better understanding how innovation is perceived in the fields of Operations Management and Service Management. Such discussion clarifies fundamental concepts of innovation, emphasizes essentials of service innovation, and gives base for future SOM research. Then, drawing from the literatures of service operations management (SOM) and innovation, a service innovation case of IKEA, Gwangmyeong in Korea, is analyzed in order to determine how both service design tools and PCN diagram can be used. The overall methodology is employed with a grounded analysis approach and an interpretative alternative. The study finds both approaches as a decision support tool and diagnostic model for assessing inputs, evaluating outputs, allocating resources, and improving success rate of service innovations in SOM.
\end{abstract}

Keywords: Process chain network, process innovation, service design tools and methods, visualizing service

\section{Introduction}

Companies of all sizes and industries need to innovate to survive [1]. Rai and Sambamurthy said that company strategies to survive in a hyper competitive global economy and gain operational excellence have led them to invest in service innovation and design [2]. Bae, Lee, and Kim said, due to the characteristics of service product, customers are usually involved in the service process taking their parts which makes the service consumption more difficult to manage and hard to control the service delivery from its failure [1]. For the last decades, there have been many approaches to visualize service operations in order to win those challenges.

Bae, Lee, and Kim claimed, as an innovative approach, many organizations have put effort on development of service design and practicing in their service process to deal with the challenges [1]. Ostrom and the fellow scholars discussed that service design has a major impact on service delivery costs, customer satisfaction, and loyalty [3]. In fact, providing a high quality customer experience plays an important role in service design and innovation according to Calabrese and Corbò [4].

A new service visualization technique, Process-Chain-Network (PCN), is introduced by Sampson [5-7] to provide a balanced view of the interaction between a customer and its service provider. It considers service as a type of resource process configuration according to Kazemzadeh, Milton, and Johnson [8]. Sampson [6] claims "PCN diagram build on the strengths of other flowcharting techniques, while emphasizing the unique conditions and design opportunities for interactive service processes". 
In this study, literatures of multiple disciplines fall under visualizing service operations will be reviewed first, and service design tools and PCN diagrams will be used in the analysis of IKEA, Gawangmyong, Korea. The empirical results may support for the effectiveness of practicing both service design tools and PCN diagrams. In addition, the service models which are visualized can help understanding how the applied tools and diagrams are assessing inputs, evaluating outputs, allocating resources, and improving success rate of service innovations in SOM.

\section{Related Studies}

\subsection{Service Operations Management (SOM)}

Although with the vast majority of economic activity in developed nations involves service operations according to Smith, Karwan, and Markland [9], Sampson claims the field of Service Operations Management (SOM) has languished in relative obscurity [5]. Operations Management is an area of management concerned with overseeing, designing, and controlling the process of production and redesigning business operations in the production of goods or services. However, Smith, Karwan, and Markland states that traditional Operations Management (OM) has focused on manufacturing management [9].

For decades, the major defining elements of SOM have come from Service Marketing (SM) such as the gap model and accompanying SERVQUAL instrument developed by Parasuraman, Zeithaml and Berry [10,11], Bitner's "servicecapes" [12], and "repositioning" of service management from an intangible product focus to a process focus by Vargo and Lusch [13]. These research models and findings are all related to Quality Management (QM) which is one major topic of SOM. As it is defined in a dictionary, marketing is the process of communicating the value of a product or service to customers, for the purpose of selling that product or service. From the tremendous successful stories and cases, we have witnessed how service marketers have established remarkable works, increased awareness, and contributed to the service industries.

In the field of SOM, ongoing researches and studies have been accomplished, for example, Chase's Customer Contact model for service design [14], Schmenner's "Service-Process Matrix" [15], and Sampson's Unified Service Theory and ProcessChain-Network Analysis [5]. QM seems both SM and SOM researchers are interested in and focus on. While SM researchers focus more on communicating the value to customers for selling, SOM researchers focus on the management overseeing, designing, and controlling the process and redesigning the business operations. It is logical for both to have common interest in QM when we apply the basic theory of the characteristic of service product, inseparability. Service inseparability simply means that the provider and the buyer are intricately linked and must be present in order for the service to be rendered. Here, now we can clearly say, SOM pays more attention on the service provider and SM on the buyers. More importantly, it is the process where both parties should keep working on and pay attention to.

\subsection{Innovation}

Andersson, Lindgren, and Henfridsson states that innovation refers to new applications of knowledge, ideas, methods, and skills that can generate unique capabilities and leverage an organization's competitiveness [16, 17]. This definition reflects a broader view of innovation by covering both administrative and technological innovation. Administrative innovation refers to the application of new 
ideas to improve organizational structures and systems, and processes pertaining to the social structure of an organization according to Weerawardena [18].

In contrast, technological innovation is defined as the adoption of new technologies that are integrated into products or processes by Yonghong, Zigang, and Kaijin [19]. Administrative innovation is often triggered by internal needs for structuring and coordination, while technological innovation mainly responds to environmental factors, such as uncertain market conditions or technical knowledge according to Gaetner and the scholars. Administrative innovation uses a top-down approach where upper level managers commit to relevant activities, whereas technological innovation applies a bottom-up approach where lower level technicians are involved [17].

Toivonen and Tuominen [21] have contributed at deepening the study about the nature of service innovation, particularly from the viewpoint of the emergence of innovations taking both theoretical and empirical approaches. In the theoretical analysis, the study focused on the clarification of the concept of service innovation examining the background theories applied: multi-disciplinary including general service theories, general innovation theories, and theories linked specifically to service innovation and its management. The empirical approach was made by using case-study method: conducting interviews, analyzing documents, and carrying out a complementary survey in the real estate and construction cluster, and examining knowledge-intensive business services (KIBS).

Tidd and Bessant [22] have emphasized on the innovation imperative and claimed that innovation is not only about an insight or idea, but it is a process. Organizations can stay successful by keeping pace with a changing environment and learning to manage innovation. According to them, innovation requires a clear strategic leadership and direction plus the commitment of resources to make it happen, an innovative organization in which the structure and climate enables people to deploy their creativity and share their knowledge to bring about change, and proactive links across boundaries inside the organization and to the many external agencies.

Two major categories of process innovations, enabling innovations and relieving innovations, were discussed by Richard Norman [23] which he called "value-space reconfigurations." While enabling innovations are visualized by moving process steps from the provider's process domain to the customer's process domain, relieving innovations are visualized by moving steps the other direction toward the provider in the PCN framework [24]. Sampson has shown how IKEA differentiates by repositioning the "assemble furniture" step from IKEA's process domain to the customers' process domain using PCN Diagram as an example case. This will be discussed further in the case analysis.

\subsection{Quality Management (QM) and Process}

Quality Management (QM) is a holistic management philosophy that fosters all functions of an organization through continuing improvement and organizational change according to Kaynak and Hartle [25]. Spencer [26] states that QM captures features from distinct organizational models and extends them by offering principles, methodologies, and techniques. Researchers emphasize that it is necessary for firms to define and develop QM practices that can assist a multidimensional management philosophy. QM practices refer to critical activities that are expected to lead, directly or indirectly, to improve quality performance and competitive advantage. Actually, researchers have provided mixed findings on the relationships among QM practices. 
It involves the responsibility of ensuring that business operations are efficient in terms of using as few resources as needed, and effective in terms of meeting customer requirements. It is concerned with managing the process that converts inputs (in the forms of materials, labor, and energy) into outputs (in the form of goods and/or services). The relationship of operations management to senior management in commercial contexts can be compared to the relationship of line officers to highest-level senior officers in military science. The highest-level officers shape the strategy and revise it over time, while the line officers make tactical decisions in support of carrying out the strategy. In business as in military affairs, the boundaries between levels are not always distinct; tactical information dynamically informs strategy, and individual people often move between roles over time.

\subsection{Service Design}

Service Design is a quite new and young phenomenon and the practices of service design tools and methods also vary and different every time [1]. The activity of design service was considered as part of the domain of marketing and management disciplines by Shostack, "How to Design a Service," who invented Service Buleprinting focusing on service design in service delivery process and its visualization $[27,28]$.

On the other hand, service design has seen where it starts with the new service development process linking it to service concept, design of operational details and to the design of service delivery process and system according to Scheuing and Johnson [29]. Many previous studies have tried to give definition of service design, but it seems to be very difficult to sort differences in approach and define any accurate and all-encompassing model. Service blueprinting is a first generation process-based approach for service design says Bitner, Ostrom, \& Morgan [30]. The critical touch points between the customer and service provider, hidden support, management activities in different layers of the organization, and all physical evidences seen by customers are represented in a service blueprint according to Kazemzadeh, Milton, and Johnson [31].

Most studies have agreed that service design is a still young, an emerging, and an interdisciplinary approach. Although with a limitation, many studies have collected and tried to sort them, for instance, more than 50 descriptions of service design methods and tools are collected according to "This is service design thinking" by Stickdorn and Schneider [32]. Each study also suggests different ways to group those service design toolkits. For example, Liedtka and Ogilvie [33] draw the design process into the four stages by asking the following questions: What is? What if? What wows? and What works?, and suggest ten tools and assign proper ones to each stage.

Another example, the 'Double Diamond' design process model by UK Service Design Council, is a simple graphical way of describing the design process which is divided into four distinct phases; Discover, Define, Develop, and Deliver. Firstly, discovery phase is the starting point where the project begins with an initial idea or inspiration. In second stage, problems are defined and interpreted. Then, different ways of tackling the problems are explored by designing and testing potential solutions in the development phase. Lastly, it represents the delivery stage where the resulting product or service is finalized and launched [36]. 


\subsection{Visualizing Service Operations}

Table 1. Visualizing Concepts from Service Models

\begin{tabular}{|c|c|c|}
\hline Models & Concept & Contribution \\
\hline $\begin{array}{l}\text { Customer } \\
\text { Contact Model } \\
\text { by Chase }\end{array}$ & $\begin{array}{l}\text { The physical presence of the } \\
\text { customer in the system: Fundamental } \\
\text { concepts of PCN Diagrams }\end{array}$ & $\begin{array}{l}\text { Split the process domain of entities } \\
\text { into four regions: Pure service, mixed } \\
\text { service, quasimanufacturing, } \\
\text { manufacturing }\end{array}$ \\
\hline $\begin{array}{l}\text { Service-Process } \\
\text { Matrix } \\
\text { by Schmenner }\end{array}$ & $\begin{array}{l}\text { The original two-dimensional } \\
\text { matrix depicted a horizontal axis of } \\
\text { "degree of customer interaction and } \\
\text { customization and horizontal axis of } \\
\text { "degree of labor intensity." }\end{array}$ & $\begin{array}{l}\text { Customer interaction and } \\
\text { customization }\end{array}$ \\
\hline $\begin{array}{l}\text { Unified Service } \\
\text { Theory } \\
\text { by Sampson }\end{array}$ & $\begin{array}{l}\text { Service as process segments that } \\
\text { involve "customer inputs" comprised } \\
\text { of customers, their belongings, and/or } \\
\text { their information }\end{array}$ & $\begin{array}{l}\text { Considers customer action (i.e. } \\
\text { customer labor) as a process input in co- } \\
\text { productive activities }\end{array}$ \\
\hline $\begin{array}{l}\text { Service } \\
\text { Blueprinting } \\
\text { by Shostack }\end{array}$ & $\begin{array}{l}\text { Differentiate between service } \\
\text { process steps that customers can see } \\
\text { above the line visibility' - and those } \\
\text { they cannot see }\end{array}$ & $\begin{array}{l}\text { Categorizes process steps according to } \\
\text { customer actions, visible employee } \\
\text { actions, invisible employee actions, } \\
\text { support processes, and managerial } \\
\text { functions (Fliess and Kleinaltenkamp, } \\
\text { 2004); Considers issues such as } \\
\text { organizational structure, physical } \\
\text { evidence, and depiction of customer roles } \\
\text { in service delivery (Bitner et al. 2008) }\end{array}$ \\
\hline $\begin{array}{l}\text { Rental Access } \\
\text { Paradigm } \\
\text { by Judd, } \\
\text { Lobelock, \& } \\
\text { Gummesson }\end{array}$ & $\begin{array}{l}\text { Two process alternatives; one is } \\
\text { firms making something tangible and } \\
\text { the transferring ownership to the } \\
\text { customer; the other is customers } \\
\text { receiving access to provider resources } \\
\text { without taking ownership- a "service" }\end{array}$ & $\begin{array}{l}\text { The paradigm makes sense for many } \\
\text { "service businesses" since customers can } \\
\text { rent or access resources owned by service } \\
\text { providers }(2004, \text { p. } 35) \text {, but not for others } \\
\text { (i.e. restaurants, custom home builders) }\end{array}$ \\
\hline $\begin{array}{l}\quad \text { Service- } \\
\text { Dominant } \\
\text { Logic by Vargo } \\
\text { \& Lusch }\end{array}$ & $\begin{array}{l}\text { Service "as the application of } \\
\text { specialized competences (knowldege } \\
\text { and skills) through deeds, processes, } \\
\text { and performances for the benefit of } \\
\text { another entity or the entity } \\
\text { itself"(Vargo and Lusch } 2004 \mathrm{a}, \text { p.2; } \\
\text { Vargo and Lusch } 2006, \text { p.43) }\end{array}$ & $\begin{array}{l}\text { Represents beneficial process skills } \\
\text { that span all regions of process domains; } \\
\text { to narrow the scope of service to not } \\
\text { include customers applying skills } \\
\text { independently for their own benefit } \\
\text { (Vargo and Lusch } 2008 \mathrm{a}, \text { p.3; Vargo and } \\
\text { Lusch } 2010, \text { p. } 141 \text { ) }\end{array}$ \\
\hline
\end{tabular}

Note. Conceptual work from Sampson [24]

\section{Methodology}

The objective of this research is to investigate the actual use of service design tools and PCN diagram used in retails sector, IKEA in Gwangmyeong in this study. The overall methodology is employed with a grounded analysis approach and an interpretative alternative. The qualitative data presented are gathered during the number of field trips. In the organization analysis, data went through number of the formal coding processes and instant and constant analysis during the process of interviews and observations. Discourse analysis has taken place during the translation process.

According to Van Maanen, the definition of qualitative techniques is as follows:

'An array of interpretative techniques which seeks to describe, decode, translate and otherwise come to terms with the meaning, not the frequency, of certain more or less naturally occurring phenomena in the social world' [34].

Therefore, the qualitative research method is chosen in order to stay close to the real experiences based on the data collected from the resorts. The constructions of reality formed by the data will be the starting point of the research to investigate the reality and gather the information. In order to increase the validity of research, the 
researcher has chosen the qualitative approaches to take the advantages of extended and intensive contacts with the interviewees.

In order to create qualitative data, the important natural language data are collected through the guided open interviews in semi structured methods [34]. As a qualitative data analysis for the obtained data, the grounded analysis is used which provides a more open approach to data analysis and is closely linked to the idea of grounded theory [35]. Qualitative research methods have been increasingly used in a wide range of academic and professional areas, especially in fields that deal with people and their behavior or experience, as an object of study.

In collecting or interviewing, the participants all wanted their identities to be confidential and agreed that the authorized information can be used for my research study. The privacy of participants will be protected and collected information will be kept and used only for the purpose of author's research.

Difference between English and Korean conversational attitude and the researcher's perspective in both languages may influence on the translation to become intercultural discourse analysis she adds. Due to the language barrier and the cultural difference from the data, the hermeneutic approach was used in order to include the prior aspects that affect communications.

\section{Case Study) IKEA, Gwangmyoung in Korea}

A worldwide company, IKEA, has opened up in Gwangmyoung, Korea on August 31,2014 . The Swedish retailer IKEA was once cited as an example of a firm that successfully executed an enabling innovation for strategic advantage (Normann, 2001; Normann and Ramirez, 1993). As Sampson's PCN Diagram has shown how IKEA differentiates by repositioning the "assemble furniture" step from IKEA's process domain to the customers' process domain, the shift has various implications for the operating characteristics and value proposition, including improved firm efficiency, reduced economies of scale, and increased customization potential [24].

The PCN Diagram of IKEA-Gwangmyoung in the consideration of strategic process positioning, study finds no steps in the region of direct interaction. Customers may avoid direct interaction altogether by using self-check-out. According to the PCN Diagram of IKEA Gwangmyoung, we may say the decreased customer intensity from having less of the process chain in regions of direct interaction and avoiding interaction further helps IKEA's efficiency and cost competitiveness. In process configuration, the key is identifying what is optimal given the need requirements from customers and the capabilities of providers.

According to the observation, the first time shoppers at IKEA are easily determined compared to the ones who have been there. IKEA-Gwangmyoung provides map, pencil, and cart for their customers. For the new shoppers at IKEA, reading a map and looking for sections where they want to be seems to be the biggest challenge. Many of them just walked through the whole shop following the arrow as they are going to visit every corner of the store. A visit to customer's center or a face to face chat with an IKEA employee is one of the options the customers may choose to help themselves. In another word, customers at IKEA need to be trained in their responsibilities.

Here, the service design tools and methods used in the IKEA-Gwangmyoung case are co-creation, observation, brainstorming, interview, shadowing, ethnography, and questionnaires. For an employee who works more on handling close personal contact with shoppers, a tool deals mostly with touch-points between service providers and customers, a customer journey map, can be used. Bitner [12] discussed three types of elements; ambient conditions, space and function, and 
signs, symbols, and artifacts, of what she calls "servicescapes," which is another service design method.

Especially, customers at IKEA need to be trained in-process, meaning in the process of experiencing and receiving service. Sampson [24] said good PCN Analysis will consider the job design for a customer, remembering that training customers is very different from training employees. He suggests more detailed PCN Diagrams for improvement by documenting customers' experiences and identifying what customers should be doing at each step and how the service environment either facilitates or distracts those customer roles. For example, the diagram reminds that a map facilitates browsing the store, a pencil helps customers note the item they need, and a cart assists in transporting items to registers.

Based on the observation and the analysis, this study finds PCN Diagrams work well more as an identifier for checking the process, evaluation of the current status and environment. Service design tools and methods may play similar functions, but each tool or method can be used properly for giving suggestions and depict possible solutions to the challenges or problems which are identified by PCN Diagrams.

\section{Conclusion}

According to the PCN analysis for IKEA furniture retail, Gwangmyeong, Korea, enabling innovations are visualized by moving process steps from the provider's process domain to the customer's process domain and relieving innovations are in the other direction. As it was previously examined, the PCN diagram shows how reposition of the 'assemble furniture' step. Each step of the diagram can be analyzed in order to determine the strategic process positioning, process control and job designing, and managing customers. To support these detailed activities and visualize service, service design tools and methods are used. This study has found PCN diagrams represent processes while the service design tools support the decision makers and service providers to practice and perform care. We are convinced by both approaches as a decision support tool and diagnostic model for assessing inputs, evaluating outputs, allocating resources, and improving success rate of service innovations in SOM.

\section{Acknowledgements}

I would like to express my sincere gratitude to my academic advisor Prof. Youn Sung Kim for the continuous support of my Ph. D study and related research.

\section{References}

[1] K. M. Bae, K. S. Lee and Y. S. Kim, "Relationship between Service Design Tools and Service Innovation - Focused on Korean Healthcare Cases", Asia-pacific Journal of Multimedia Service Convergent with Art, Humanities, and Sociology, vol. 4, no. 2, (2014) December, pp. 63-70.

[2] A. Rai and V. Sambamurthy, "The growth of interest in services management: Opportunities for information systems scholars", Information Systems Research, vol. 17, no. 4, (2006), pp. 327-331.

[3] A. L. Ostrom, M. J. Bitner, S. W. Brown, K. A. Burkhard, M. Goul, V. Smith-Daniels, H. Demirkan and E. Rabinovich, "Moving forward and making a difference: Research priorities for the science of service", Journal of Service Research, vol. 13, no. 1, (2010), pp. 4-36.

[4] A. Calabrese and M. Corbò, "Design and blueprinting for total quality management implementation in service organizations", Total Quality Management \& Business Excellence, (2014), pp. 1-14.

[5] S. E. Sampson, "Introduction to PCN analysis", Provo, Utah, USA, vol. 15, (2011), pp. 1-16.

[6] S. E. Sampson, "Essentials of service design (Second Edi.)", Provo, Utah, USA: Brigham Young University, (2012a).

[7] S. E. Sampson, "Visualizing service operations", Journal of Service Research, vol. 15, no. 2, (2012b), pp. 182-198.

[8] Y. Kazemzadeh, S. K. Milton and L. W. Johnson, "Process chain Network (PCN) and business process modeling notation (BPMN): a comparison of concepts", Journal of Management and Strategy, vol. 6, no. 
1, (2015), pp. 88-99.

[9] J. S. Smith, K. R. Karwan and R. E. Markland, "A Note on the Growth of Research in Service Operations Management”, Production and Operations Management, vol. 16, no. 6, (2007) NovemberDecember, pp. 780-790.

[10] A. Parasuraman, V. A. Zeithaml and L. L. Berry, "A conceptual model of service quality and its implications for future research", Journal of Marketing, vol. 49, no. 4, (1985) September, pp. 41-50.

[11] A. Parasuraman, V. A. Zeithaml and L. L. Berry, "SERVQUAL: A multiple-item scale for measuring consumer perceptions of service quality", Journal of Retailing, vol. 64, no. 1, (1988), pp. 12.

[12] M. J. Bitner, "Servicescapes: The impact of physical surroundings on customers and employees", Journal of Marketing, vol. 56, no. 2, (1992), pp. 57-71.

[13] S. L. Vargo and R. F. Lusch, "Evolving to a New Dominant Logic", Journal of Marketing, vol. 68, no. 1, (2004), pp. 1-17.

[14] R. B. Chase, "Where Does the Customer Fit in a Service Operation?", Harvard Business Review, vol. 56, no. 6, (1978) November-December, pp. 137-142.

[15] R. W. Schmenner, "How Can Service Businesses Survive and Prosper?", Sloan Management Review, vol. 27, no. 3, (1986), Spring, pp. 21-32.

[16] M. Andersson, R. Lindgren and O. Henfridsson, "Architectural knowledge in interorganizational IT innovation", Journal of Strategic Information Systems, vol. 17, no. 1, (2008) April, pp. 19-38.

[17] M. J. Bitner, "Servicescapes: The impact of physical surroundings on customers and employees", Journal of Marketing, vol. 56, no. 2, (1992), pp. 57.

[18] R. L. Daft, "A dual-core model of organizational innovation", Academy of Management Journal, vol. 21, no. 2, (1978), pp. 193-210.

[19] J. Weerawardena, "The role of marketing capability in innovation based competitive strategy", Journal of Strategic Marketing, vol. 11, no. 1, (2003), pp. 15-36.

[20] Z. Yonghong, Z. Zigang and L. Kaijin, "Impact of technological innovation on growth trajectory of enterprise's technological capability: a theoretical analysis", Singapore Management Review, vol. 27, no. 2, (2005), pp. 81-101.

[21] G. H. Gaertner, K. N. Gaertner and D. M. Akinnusi, "Environment, strategy, and the implementation of administrative change: the case of civil service reform", Academy of Management Journal, vol. 27, no. 3, (1984), pp. 525-543.

[22] M. Toivonen and T. Tuominen, "Emergence of innovations in services", The Service Industries Journal, vol. 29, no. 7, (2009), pp. 887-902.

[23] Tidd and Bessant, "Innovation", In: Strategic Operations Management $3^{\text {rd }}$ Edition, Brown, Bessant, and Lamming, Routledge, (2013).

[24] R. Norman, "Reframing Business: When the Map Changes the Landscape", John Wiley \& Sons, Hoboken, New Jersey, (2001).

[25] S. E. Sampson, "Essentials of Service Design and Innovation", (Third Edi.). Provo, Utah, USA: Brigham Young University, (2014).

[26] H. Kaynak and J. L. Hartley, "Exploring quality management practices and high tech firm performance", J. High Technol. Manag. Res. vol. 16, no. 2, (2005), pp. 255-272.

[27] B. A. Spencer, "Models of organization and total quality management: a comparison and critical evaluation", The Academy of Management Review, vol. 19, no. 3, (1994), pp. 446-471.

[28] G. L. Shostack, "How to Design a Service", European Journal of Marketing, vol. 16, no. 1, (1982), pp. 49-62.

[29] G. L. Shostack, "Designing services that deliver", Harvard Business Review, (1984) January-February, pp. 133-139.

[30] E. Scheuing and E. Johnson, "Proposed Model for New Service Development", The Journal of Services Marketing, (1989).

[31] M. J. Bitner, A. L. Ostrom and F. N. Morgan, "Service blueprinting: A practical technique for service innovation”, California Mnagement Review, vol. 50, no. 3, (2008), pp. 66-94.

[32] Y. Kazemzadeh, S. K. Milton and L. W. Johnson, "A Comparison of Concepts in Service Blueprinting and Process-Chain-Network (PCN)", International Journal of Business and Management, vol. 10, no. 4, (2015), pp. 13-25.

[33] M. Stickdorn and J. Schneider, "This Is Service Design Thinking", Hoboken, New Jersey: John Wiley \& Sons, Inc., (2011).

[34] J. Liedtka and T. Ogilvie, "Designing for Growth: a design thinking tool kit for managers", Chichester, West Sussex: Columbia University Press, (2011).

[35] M. Easterby-Smith, R. Thorpe and A. Lowe, "Management Research", Sage Publications, (2008), pp. $142-153$

[36] M. Easterby-Smith, R. Thorpe and P. R. Jackson, "Management Research", Sage Publications, (2009), pp. 175.

[37] K. M. Bae and Y. S. Kim, "Empirical Study of Service Design Tools and Process-Chain Network (PCN)", Science \& Engineering Research Support Society, vol. 102, (2015), pp. 70-73. 